\title{
Effects of a commercial fermentation byproduct or urea on milk production, rumen metabolism, and omasal flow of nutrients in lactating dairy cattle
}

\author{
S. W. Fessenden, ${ }^{1}$ A. Foskolos, ${ }^{1}$ T. J. Hackmann, ${ }^{2}$ D. A. Ross, ${ }^{1}$ E. Block, ${ }^{3}$ and M. E. Van Amburgh ${ }^{1 *}$ \\ ${ }^{1}$ Department of Animal Science, Cornell University, Ithaca, NY 14850 \\ ${ }^{2}$ Department of Animal Sciences, University of Florida, Gainesville 32611 \\ ${ }^{3}$ Arm and Hammer Animal Nutrition, Princeton, NJ 08543
}

\section{ABSTRACT}

The objective of this study was to evaluate the effects of a fermentation byproduct on rumen fermentation and microbial yield in high producing lactating dairy cattle. Eight ruminally cannulated multiparous Holstein cows averaging (mean \pm standard deviation) $60 \pm 10 \mathrm{~d}$ in milk and $637 \pm 38 \mathrm{~kg}$ of body weight were assigned to 1 of 2 treatment sequences in a switchback design. Treatment diets contained (dry matter basis) $44 \%$ corn silage, $13 \%$ alfalfa silage, $12 \%$ ground corn, and $31 \%$ premix containing either a control mix of urea and wheat middlings $(\mathrm{CON})$ or a commercial fermentation byproduct meal (Fermenten, Arm and Hammer Animal Nutrition, Princeton, NJ) at 3\% diet inclusion rate (EXP). Diets were formulated to be isonitrogenous and isocaloric, with similar levels of neutral detergent fiber and starch. The trial consisted of three 28-d experimental periods, where each period consisted of $21 \mathrm{~d}$ of diet adaptation and $7 \mathrm{~d}$ of data and sample collection. Omasal nutrient flows were determined using a triplemarker technique and double-labeled ${ }^{15} \mathrm{~N}^{15} \mathrm{~N}$-urea. The EXP diet provided $18 \mathrm{~g} / \mathrm{d}$ more nonammonia $\mathrm{N}$ versus the CON diet, representing 3.0\% of total $\mathrm{N}$ intake. Energy-corrected milk yield (41.7 and $43.1 \mathrm{~kg} / \mathrm{d}$ for CON and EXP, respectively), milk fat, and protein yield and content did not differ between treatments. Total dry matter intake was similar between treatments (25.5 and $26.4 \mathrm{~kg} / \mathrm{d}$ for CON and EXP, respectively). Ammonia $\mathrm{N}$ concentration and pool size in the rumen was greater in cows fed the EXP diet. No differences were observed in rumen or total-tract dry matter, organic matter, or neutral detergent fiber digestibility. Ruminal degradation of feed $\mathrm{N}$ was $15 \%$ lower in cows fed EXP diets, resulting in differences in omasal $\mathrm{N}$ flows. Results demonstrated the fermentation byproduct meal had a

Received July 26, 2018.

Accepted December 18, 2018.

*Corresponding author: mev1@cornell.edu sparing effect on degradable feed protein, but did not increase microbial $\mathrm{N}$ flow from the rumen.

Key words: omasal sampling, soluble protein, Cornell Net Carbohydrate and Protein System, microbial protein synthesis, Fermenten

\section{INTRODUCTION}

Protein is one of the most expensive macronutrients in dairy cattle rations, and overfeeding degradable protein results in excessive $\mathrm{N}$ losses to the environment (Huhtanen and Hristov, 2009). Efficient use of feed $\mathrm{N}$ can be achieved by first meeting the requirements of the rumen microbial population, followed by balancing diets to meet the AA requirements of the cow. To decrease competition for quality protein that could otherwise be fed to humans, dairy cattle are fed byproducts of human food production, thereby converting waste product streams into highly valuable milk protein. One such byproduct of commercial AA production is Fermenten (Arm and Hammer Animal Nutrition, Princeton, NJ). Commercial AA production is performed using bacterial cultures, resulting in a waste stream with high amounts of soluble nitrogenous compounds (Fessenden, 2016). These compounds of bacterial origin are in the highly available forms of ammonia, free AA, small peptides, and purines. Amino acids and peptides have been hypothesized to increase the flow of microbial protein from the rumen through stimulation of microbial protein synthesis (Cotta and Russell, 1982; Lean et al., 2005). Increased microbial N flow also reduces reliance on expensive rumen undegradable dietary protein sources commonly used to provide AA to high producing dairy cattle. Previous research with varying sugar levels suggested that these fermentation byproducts might only affect certain microbial populations (Penner et al., 2009).

Mathematical models such as the Cornell Net Carbohydrate and Protein System (CNCPS; Higgs et al., 2015; Van Amburgh et al., 2015) have been successfully used to optimize rumen microbial output and meet 
nutrient requirements of cattle while reducing $\mathrm{N}$ losses to the environment (Tylutki et al., 2008). Successful use of such models requires accurate characterization of the metabolizable AA outflows from the rumen. The omasal sampling technique developed by Huhtanen et al. (1997) and modified by Ahvenjärvi et al. (2000) provides useful data to assess the accuracy of model predictions of ruminal digestion and flow of AA to the small intestine (Fessenden and Van Amburgh, 2016).

The hypothesis of this study was that inclusion of a fermentation byproduct with soluble AA and peptides versus a wheat middlings and urea control blend would increase postruminal NAN flow at the omasal canal. The specific objectives of this study were to (1) evaluate the effect of urea or soluble AA and peptides from a commercial fermentation byproduct on rumen digestion and omasal flows of nutrients, and (2) provide comparisons of model predicted versus measured values for rumen $\mathrm{N}$ outflows.

\section{MATERIALS AND METHODS}

The experiment was conducted from April to July 2014 at the Cornell University Ruminant Center in Harford, New York. All animals involved in this experiment were cared for according to the guidelines of the Cornell University Animal Care and Use committee. The committee reviewed and approved the experiment and all procedures carried out in the study.

\section{Animals and Experimental Design}

Eight ruminally cannulated multiparous Holstein cows averaging (mean $\pm \mathrm{SD}$ ) $60 \pm 10 \mathrm{DIM}$ and 637 $\pm 38 \mathrm{~kg}$ of $\mathrm{BW}$ were enrolled in a 3 wk pretrial acclimation period where all animals were managed and housed in a tiestall and individually fed a common diet. The pretrial diet consisted of $42 \%$ corn silage, $11 \%$ alfalfa silage, $15 \%$ ground corn, and $32 \%$ protein premix. At the end of the 3 -wk period, animals were stratified by pretrial milk production and randomly assigned to 1 of 2 treatment sequences in a switchback design. The trial consisted of three 28-d experimental periods, where each period contained $21 \mathrm{~d}$ for diet adaptation and $7 \mathrm{~d}$ of data and sample collection. All cows were injected on d 1 with bovine somatotropin (500 $\mathrm{mg}$ of Posilac, Elanco Animal Health, Greenfield, IN) and at 14-d intervals thereafter for the entire trial. Cows were milked $3 \times$ daily at 0600, 1400, and $2200 \mathrm{~h}$ through a parlor except during sampling periods, when cattle were milked in the tiestalls. Milk yield was recorded and milk samples taken at each milking on d 21, 22, and 23 of each period and analyzed for fat, true protein, lactose, SCC, TS, and MUN at a commercial laboratory
(DairyOne, Ithaca, NY). Body weights were measured weekly after the $1400 \mathrm{~h}$ milking, and BCS was recorded weekly as the average of 2 trained scorers. Change in BW and BCS were calculated as the difference between measurements taken on d 28 of each period.

\section{Treatment Administration and Sample Collection}

Treatment diets contained (DM basis) $44 \%$ corn silage, $13 \%$ alfalfa silage, $12 \%$ ground corn, and $31 \%$ premix containing either a control mix of urea and wheat middlings (CON) or Fermenten (EXP) at $3 \%$ inclusion rate in the final diet (Table 1). The premixes also differed slightly in mineral sources to account for a higher level of sulfates in Fermenten. The EXP diet contained calcium carbonate, whereas CON contained calcium sulfate (Table 1). Forages and other ingredients were analyzed for chemical composition for use in the CNCPS v. 6.5 using wet chemical methods by Cumberland Valley Analytical Services (Hagerstown, $\mathrm{MD})$. Rumen degradable protein and $\mathrm{NH}_{3}-\mathrm{N}$ balance for CON and EXP diets as predicted by the CNCPS v. 6.5 were 8.2 and $7.8 \%$ of DM and 120 and $115 \%$ of the $\mathrm{NH}_{3}-\mathrm{N}$ requirement, respectively. The forage and corn grain portion of the diets were mixed daily as a single batch and delivered to the cattle housing facility, where the batch was split in half and either the CON or EXP protein premix was added to complete the treatment diets. Final mixing was done in a Super Data Ranger (American Calan Inc., Northwood, NH) and the resulting TMR was offered once daily at $0700 \mathrm{~h}$. Orts were collected and weights recorded at $0600 \mathrm{~h}$, and feeding rate was adjusted daily to yield orts of 5 to $10 \%$ of daily intake. Weekly samples of corn silage, alfalfa silage, corn grain, protein premixes, and TMR were analyzed for $\mathrm{DM}$ by drying at $60^{\circ} \mathrm{C}$ for $48 \mathrm{~h}$, and diets were adjusted to maintain the intended formulation. Dried samples were ground through a 1-mm screen (Wiley no. 4 mill, Arthur H. Thomas, Philadelphia, PA), composited by period, and analyzed for nutrient composition (Tables 1 and 2). Intake of DM was calculated from DM determinations on TMR and orts. During sampling days, daily samples of TMR and orts were processed in the same manner as above, and equal parts DM from each sampling day were combined to create a sampling period composite for each cow within period.

\section{Marker Infusion and Omasal Sampling}

During the last week of each period, cows entered the infusion and omasal sampling phase. A triple marker system using CoEDTA (Udén et al., 1980), $\mathrm{YbCl}_{3}$ (modified from Siddons et al., 1985), and undigested amylase- and sodium sulfite-treated NDF corrected 
Table 1. Chemical composition (mean $\pm \mathrm{SD})^{1}$ of select feeds used in the experiment

\begin{tabular}{lrcc}
\hline Item $^{2}$ & Corn silage & Alfalfa silage & Fermenten $^{3}$ \\
\hline DM, \% & $32.6 \pm 0.7$ & $33.7 \pm 0.9$ & 90.1 \\
CP, \% of DM & $7.3 \pm 0.4$ & $21.8 \pm 0.6$ & 51.1 \\
Soluble protein, \% of CP & $57.2 \pm 2.7$ & $61.3 \pm 3.7$ & 77.1 \\
NDICP, \% of CP & $14.3 \pm 1.2$ & $10.7 \pm 1.2$ & 1.3 \\
ADICP, \% of CP & $11.4 \pm 0.3$ & $8.8 \pm 1.0$ & 4.0 \\
aNDFom, \% of DM & $40.0 \pm 2.6$ & $40.3 \pm 2.0$ & 23.6 \\
30-h uNDFom, \% of aNDFom & $46.2 \pm 2.1$ & $52.4 \pm 3.0$ & - \\
120-h uNDFom, \% of aNDFom & $29.6 \pm 1.0$ & $46.5 \pm 2.7$ & - \\
240-h uNDFom, \% of aNDFom & $25.1 \pm 1.8$ & $42.3 \pm 2.6$ & 23.8 \\
ADF, \% of DM & $26.2 \pm 2.2$ & $34.2 \pm 2.2$ & 2.5 \\
ADL, \% of DM & $3.2 \pm 0.2$ & $7.9 \pm 0.6$ & 14.8 \\
Starch, \% of DM & $33.6 \pm 1.8$ & $1.0 \pm 0.5$ & 2.9 \\
Ether extract, \% of DM & $3.5 \pm 0.1$ & $4.0 \pm 0.3$ & 5.9 \\
Ash, \% of DM & $3.1 \pm 0.1$ & $11.0 \pm 0.4$ & \\
\hline
\end{tabular}

${ }^{1}$ Analyzed values from 3 period composite samples.

${ }^{2} \mathrm{NDICP}=$ neutral detergent insoluble CP; ADICP $=$ acid detergent insoluble CP; aNDFom = amylase- and sodium sulfite-treated NDF corrected for ash residue; uNDFom = undigested amylase- and sodium sulfitetreated NDF corrected for ash residue.

${ }^{3}$ Arm and Hammer Animal Nutrition, Princeton, NJ. Single batch/lot used for entire experiment.

for ash residue after $240 \mathrm{~h}$ of in vitro fermentation (uNDFom; Raffrenato et al., 2018) were used to quantify liquid, small particle, and large particle flow at the omasal canal, respectively. Cobalt-EDTA and $\mathrm{YbCl}_{3}$ were dissolved in distilled water and continuously infused into the rumen at rates of $2.8 \mathrm{~g} / \mathrm{d}$ of Co and $3.4 \mathrm{~g} / \mathrm{d}$ of $\mathrm{Yb}$ in $2.75 \mathrm{~L}$ of solution/d. All animals received a 3 - $\mathrm{L}$ priming dose of the $\mathrm{Co}$ and $\mathrm{Yb}$ solution immediately before infusion start, providing $3.05 \mathrm{~g}$ of $\mathrm{Co}$ and $3.71 \mathrm{~g}$ of $\mathrm{Yb}$ per cow. On d 21 of each period, cattle were fitted with an indwelling catheter (Microrenathane tubing, Braintree Scientific Inc., Braintree, MA) in the jugular vein for infusion of the microbial marker. Double-labeled urea $\left({ }^{15} \mathrm{~N}^{15} \mathrm{~N}\right.$-urea, $98 \%$ purity, Cambridge Isotope Laboratories Inc., Andover, MA) in sterile saline $(9 \mathrm{~g}$ of $\mathrm{NaCl} / \mathrm{L})$ was continuously infused a rate of $150 \mathrm{~mL} / \mathrm{d}$, providing $0.675 \mathrm{~g} / \mathrm{d}$ of ${ }^{15} \mathrm{~N}^{15} \mathrm{~N}$-urea. Before starting the infusion, samples of whole ruminal contents, feces, urine, plasma, and rumen microbes were taken for determination of ${ }^{15} \mathrm{~N}$ background. All markers were infused continuously from $1400 \mathrm{~h}$ on d 21 until $1000 \mathrm{~h}$ on d 28 of each period via peristaltic pump (Masterflex, Cole-Parmer Instrument Company, LLC, Vernon Hills, IL). All cows had at least $72 \mathrm{~h}$ of continuous infusion to reach uniform marker distribution before any sampling occurred, as suggested by Broderick and Merchen (1992) and conducted previously in our laboratory (Marini and Van Amburgh, 2003; Recktenwald, et al., 2014).

Omasal samples were obtained using the omasal sampling technique developed by Huhtanen et al. (1997) and adapted by Reynal and Broderick (2005). Samples of whole omasal contents were collected from the omasal canal at 2-h intervals during three 8-h sessions: at
1600, 1800, 2000, and $2200 \mathrm{~h}$ on d 24; at 0000, 0200, 0400 , and $0600 \mathrm{~h}$ on d 26; and at 0800, 1000, 1200, and 1400 on $d 27$. The sampling device was removed at the end of each 8-h sampling session, and re-inserted at the start of the next session. Sampling times were chosen to encompass every $2 \mathrm{~h}$ of the average 24 -h feeding cycle. During each 8-h session, a 425-mL spot sample was obtained at the first 3 time points, whereas $675 \mathrm{~mL}$ was taken at the last time point. Spot omasal content samples were split into subsamples of $50 \mathrm{~mL}(\times 2), 125$ $\mathrm{mL}$, and $200 \mathrm{~mL}$, with an additional $250-\mathrm{mL}$ subsample at the last time point. One of the 50-mL samples (OF) was filtered through cheesecloth, acidified with $1 \mathrm{~mL}$ of $50 \% \mathrm{H}_{2} \mathrm{SO}_{4}$, combined within period, and stored at $-20^{\circ} \mathrm{C}$ for subsequent $\mathrm{NH}_{3}-\mathrm{N}$ and VFA analysis, and the other was processed and stored for a separate investigation of soluble NAN flows. The 125-mL subsamples were held on ice and combined within session, yielding a 500-mL sample for bacterial isolation. The 200-mL samples were combined within period and stored at $-20^{\circ} \mathrm{C}$, yielding a $2.4-\mathrm{L}$ composite for digestion phase separation. The additional $250-\mathrm{mL}$ sample obtained at the end of each session was immediately processed to isolate protozoa (OP) using flocculation and filtration techniques, as described in the companion paper (Fessenden et al., 2019) for investigation of microbial $\mathrm{N}$ and AA flows.

The bacterial isolations from each 8-h session were combined within sampling period to yield an omasal bacteria (OB) sample for each cow within period. Isolation was performed according to Whitehouse et al. (1994) with modifications. Briefly, whole omasal contents were filtered through 4 layers of cheesecloth and solids were rinsed once with saline, and the filtrate 
(I) was treated with formalin $(0.1 \% \mathrm{vol} / \mathrm{vol}$ in final solution) and stored at $4^{\circ} \mathrm{C}$. The solids retained on the cheesecloth were incubated for $1 \mathrm{~h}$ at $39^{\circ} \mathrm{C}$ in a $0.1 \%$ methylcellulose solution, mixed for 1 min at low speed (Omni Mixer, Omni International, Kennesaw, GA) to detach solid-associated bacteria, and held at $4^{\circ} \mathrm{C}$ for 24 h. The contents were then squeezed through 4 layers of cheesecloth and the filtrate (II) was treated with formalin $(0.1 \% \mathrm{vol} / \mathrm{vol}$ in final solution). Filtrates I and II

Table 2. Ingredient and nutrient composition (mean $\pm \mathrm{SD})^{1}$ of experimental diets

\begin{tabular}{|c|c|c|}
\hline \multirow[b]{2}{*}{ Item } & \multicolumn{2}{|c|}{$\operatorname{Diet}^{2}$} \\
\hline & $\mathrm{CON}$ & EXP \\
\hline \multicolumn{3}{|l|}{ Ingredient composition, \% DM } \\
\hline Corn silage & 44.6 & 44.6 \\
\hline Alfalfa silage & 12.0 & 12.0 \\
\hline Corn meal & 12.0 & 12.0 \\
\hline Expeller soybean meal ${ }^{3}$ & 8.0 & 8.0 \\
\hline Soybean hulls & 5.8 & 5.8 \\
\hline Citrus pulp, dry & 3.3 & 3.3 \\
\hline Chocolate meal & 2.4 & 2.4 \\
\hline $\mathrm{SFA}^{4}$ & 1.2 & 1.2 \\
\hline Molasses & 0.9 & 0.9 \\
\hline Blood meal & 1.7 & 1.7 \\
\hline Wheat middlings & 4.8 & $\begin{array}{l}1.1 \\
3.2\end{array}$ \\
\hline Fermentation byproduct $^{5}$ & - & 3.0 \\
\hline Calcium carbonate & - & 0.7 \\
\hline Urea & 0.4 & - \\
\hline Calcium sulfate, dihydrate & 1.7 & - \\
\hline Sodium bicarbonate & 0.33 & 0.40 \\
\hline Salt white & 0.30 & 0.32 \\
\hline Magnesium oxide & 0.17 & 0.17 \\
\hline Dicalcium phosphate & 0.16 & 0.16 \\
\hline Supplemental methionine ${ }^{6}$ & 0.06 & 0.06 \\
\hline Vitamin and mineral mix ${ }^{7}$ & 0.18 & 0.18 \\
\hline \multicolumn{3}{|l|}{ Nutrient composition } \\
\hline DM, \% & $44.5 \pm 0.7$ & $44.2 \pm 0.8$ \\
\hline OM. $\%$ of DM & $93.9 \pm 0.3$ & $93.8 \pm 0.6$ \\
\hline $\mathrm{CP}, \%$ of DM & $15.9 \pm 0.6$ & $16.1 \pm 0.5$ \\
\hline $\mathrm{RDP}^{8} \%$ of DM & $8.4 \pm 0.1$ & $8.0 \pm 0.1$ \\
\hline Starch, $\%$ of DM & $27.5 \pm 1.1$ & $27.8 \pm 0.5$ \\
\hline Sugars, \% of DM & $5.4 \pm 0.4$ & $5.3 \pm 0.3$ \\
\hline NFC, ${ }^{8} \%$ of DM & $41.7 \pm 0.2$ & $41.8 \pm 1.3$ \\
\hline aNDFom, ${ }^{9} \%$ of DM & $30.9 \pm 0.2$ & $31.2 \pm 0.2$ \\
\hline $\mathrm{ADF}, \%$ of $\mathrm{DM}$ & $19.9 \pm 1.5$ & $19.7 \pm 0.6$ \\
\hline $\mathrm{ADL}, \%$ of $\mathrm{NDF}$ & $10.0 \pm 0.9$ & $10.0 \pm 1.4$ \\
\hline Ether extract. \% of DM & $5.0 \pm 0.2$ & $4.9 \pm 0.2$ \\
\hline $\mathrm{ME}{ }^{8} \mathrm{Mcal} / \mathrm{kg}$ & $2.5 \pm 0.1$ & $2.5 \pm 0.1$ \\
\hline
\end{tabular}

${ }^{1}$ Analyzed values from 3 period composite samples.

${ }^{2} \mathrm{CON}=3 \%$ of diet DM as urea control mix; EXP $=3 \%$ of $\operatorname{diet} \mathrm{DM}$ as fermentation byproduct.

${ }^{3}$ Soyplus (West Central Cooperative, Ralston, IA).

${ }^{4}$ Energy Booster 100 (MSC Company, Eden Prairie, MN).

${ }^{5}$ Fermenten (Arm and Hammer Animal Nutrition, Princeton, NJ).

${ }^{6}$ Smartamine M (Bluestar Adisseo Nutrition Group, Alpharetta, GA).

${ }^{7}$ Provided (per $\mathrm{kg}$ of diet DM): $44 \mathrm{mg}$ of $\mathrm{Zn}, 32 \mathrm{mg}$ of $\mathrm{Mn}, 10 \mathrm{mg}$ of $\mathrm{Cu}, 1 \mathrm{mg}$ of Co, $1 \mathrm{mg}$ of I, $0.3 \mathrm{mg}$ of Se, $5,000 \mathrm{IU}$ of vitamin A, $980 \mathrm{IU}$ of vitamin $\mathrm{B}$, and $25 \mathrm{IU}$ of vitamin $\mathrm{E}$.

${ }^{8}$ Calculated by the Cornell Net Carbohydrate and Protein System v. 6.5 (Van Amburgh et al., 2015).

${ }^{9}$ aNDFom $=$ amylase- and sodium sulfite-treated NDF corrected for ash residue. were then combined and centrifuged at $1,000 \times g$ for 5 min at $4^{\circ} \mathrm{C}$ to remove small feed particles and protozoa. The supernatant was centrifuged at $15,000 \times g$ for 20 min at $4^{\circ} \mathrm{C}$ and the bacterial pellet, representing both solid- and liquid-associated bacteria, was collected and stored at $-20^{\circ} \mathrm{C}$ until lyophilization and later analysis.

Spot fecal and rumen fluid (RF) samples were taken at the same time points as omasal spot samples. Fecal samples were composited by period and stored at $-20^{\circ} \mathrm{C}$, whereas $\mathrm{RF}$ was filtered through cheesecloth, acidified with $50 \% \mathrm{H}_{2} \mathrm{SO}_{4}$, and composited by period before storage at $-20^{\circ} \mathrm{C}$. On d 24 of each period, a sample of whole rumen contents was taken $4 \mathrm{~h}$ after feeding for isolation of rumen microbes. Spot urine and blood samples were taken at the second time point of each session. Blood samples were collected into tubes containing sodium heparin, centrifuged $(3,000 \times g$ for $20 \mathrm{~min}$ at $4^{\circ} \mathrm{C}$ ), and plasma was harvested and stored at $-20^{\circ} \mathrm{C}$. Urine samples were immediately acidified to $\mathrm{pH}<2$ with $50 \% \mathrm{H}_{2} \mathrm{SO}_{4}$ and stored at $-20^{\circ} \mathrm{C}$. On the last day of each period, rumen contents were evacuated, weighed, mixed, and a representative sample was obtained and stored at $-20^{\circ} \mathrm{C}$. Rumen contents were returned to the cow via the rumen cannula within 30 min of evacuation.

\section{Sample Processing and Chemical Analysis}

Sampling period TMR and orts composites were analyzed for $\mathrm{DM}$ at $105^{\circ} \mathrm{C}$ for $6 \mathrm{~h}$ and ash according to AOAC International (2005), and for total $\mathrm{N}$ using a combustion assay (Leco FP-528 N Analyzer, Leco Corp., St. Joseph, MI). Composited TMR and orts samples were analyzed for amylase- and sodium sulfite-treated NDF corrected for ash residue (aNDFom; Mertens, 2002 ), and uNDFom after $240 \mathrm{~h}$ of in vitro incubation with RF, according to Raffrenato et al. (2018). The 2.4-L pooled omasal composites were thawed and separated into omasal large particle $(\mathbf{L P})$, small particle (SP), and liquid phases (LQ) as described by Reynal and Broderick (2005). All phase samples were freezedried and either ground through a 1-mm screen on a Wiley mill (LP) or homogenized with a mortar and pestle (SP and LQ) before analysis. Concentration of $\mathrm{Co}$ and $\mathrm{Yb}$ was determined by ICM-MS in all phase samples (Cornell University Nutrient Analysis Laboratory, Ithaca, NY) and the LP and SP phases were analyzed for uNDFom as described above. All omasal phases were analyzed for DM, OM, aNDFom, and total $\mathrm{N}$ as described previously for feed samples to determine ruminal digestion and flow parameters. Concentrations of $\mathrm{Yb}, \mathrm{Co}$, and uNDFom in each phase were used to calculate the concentration of each nutrient in a theoretical entity representing omasal true digesta (OTD; 
France and Siddons, 1986). As such, the reported flows and concentrations of any given nutrient in OTD are a mathematical calculation based on re-constitution factors determined using the triple marker technique and measured values of the nutrient in LQ, SP, and LP. This mathematical construct is referred to in this paper as OTD. Composite fecal samples were thawed, thoroughly mixed, and a subsample was dried for $72 \mathrm{~h}$ at $60^{\circ} \mathrm{C}$ in a forced-air oven. Subsamples from rumen evacuations were freeze-dried and the dried feces and rumen contents were ground to pass a 1-mm screen on a Wiley mill. Dry matter, OM, total N, aNDFom, and uNDFom were determined on the dried ground feces for total-tract digestibility, whereas rumen contents were analyzed for DM and OM. Ammonia N concentration was determined in $\mathrm{RF}$ and $\mathrm{OF}$ using the colorimetric method of Chaney and Marbach (1962). Urea N concentration was determined in plasma and urine using an enzymatic colorimetric assay based on a commercial kit (No. 640, Sigma-Aldrich, St. Louis, MO). Volatile fatty acid concentration in $\mathrm{RF}$ and $\mathrm{OF}$ was determined by HPLC (Agilent 1100 series HPLC, Agilent Technologies, Santa Clara, CA) using crotonic acid as an internal standard (Siegfried et al., 1984).

Samples of OB, OP, rumen contents, and omasal digesta phases were analyzed for NAN concentration and ${ }^{15} \mathrm{~N}$ enrichment as follows: $20 \mu \mathrm{g}$ of $\mathrm{N}$ from each sample was weighted into tin capsules and $10 \mu \mathrm{L}$ of 72 $\mathrm{m} M \mathrm{~K}_{2} \mathrm{CO}_{3}$ was added and incubated at $60^{\circ} \mathrm{C}$ overnight to volatilize ammonia. Samples were then analyzed for NAN and ${ }^{15} \mathrm{~N}$ using a Carlo Erba NC2500 elemental analyzer (Thermoquest, Milan, Italy) interfaced with an isotope ratio mass spectrometer (Cornell University Stable Isotope Laboratory, Ithaca, NY). Samples of rumen bacteria, protozoa, and contents for natural abundance of ${ }^{15} \mathrm{~N}$ were prepared and analyzed separately in the same manner as the enriched samples.

\section{Calculations}

Total digesta $\mathrm{N}$ entering the omasal canal was calculated using the triple marker technique and partitioned into 3 fractions: ammonia N, microbial $\mathrm{N}$, and nonammonia, nonmicrobial N (NANMN). Ammonia N flow was determined using the concentration of ammonia $\mathrm{N}$ in the $\mathrm{OF}$ sample and the flow of liquid determined using the triple marker system. Total NAN flow was calculated as the difference between total $\mathrm{N}$ and ammonia N. Microbial N flow was determined using ${ }^{15} \mathrm{~N}$ atom percent excess (APE) in OTD and ${ }^{15} \mathrm{~N}$ APE of the OB and OP samples. The APE was calculated for digesta and microbial samples for each cow within period as follows:

$$
\begin{gathered}
{ }^{15} \mathrm{~N} \text { APE }=\left(\text { enriched }{ }^{15} \mathrm{~N} \text {-atom } \%\right. \text { - mean natural } \\
\left.{ }^{15} \mathrm{~N} \text {-atom } \%\right) / \text { mean natural }{ }^{15} \mathrm{~N} \text {-atom } \%
\end{gathered}
$$

Mean natural abundance of ${ }^{15} \mathrm{~N}$ in rumen bacteria, protozoa, and contents was $0.3684 \pm 0.0002$ (mean $\pm \mathrm{SD}$ ). The natural abundance of ${ }^{15} \mathrm{~N}$ in rumen bacteria, protozoa, and contents was assumed to be representative of $\mathrm{OB}, \mathrm{OP}$, and OTD, respectively. Protozoa biomass flow was calculated using gravimetric determinations of protozoa DM in omasal liquid multiplied by protozoa NAN content and daily omasal liquid flow. The ${ }^{15} \mathrm{~N}$ APE in protozoa and bacteria was then used to calculate total microbial $\mathrm{N}$ flow:

$$
\begin{gathered}
\text { Omasal protozoa NAN flow }(\mathrm{g} / \mathrm{d})= \\
\text { OP DM flow }(\mathrm{g} / \mathrm{d}) \times \text { OP NAN }(\mathrm{g} / \mathrm{g} \text { of } \mathrm{DM}), \\
\text { Omasal bacteria NAN flow }(\mathrm{g} / \mathrm{d})= \\
\left\{\left[\text { OTD NAN flow }(\mathrm{g} / \mathrm{d}) \times \text { OTD }{ }^{15} \mathrm{~N} \text { APE }(\mathrm{g} / \mathrm{g} \text { of } \mathrm{N})\right]\right. \\
-\left[\text { OP NAN flow }(\mathrm{g} / \mathrm{d}) \times \text { OP }{ }^{15} \mathrm{~N} \mathrm{APE}\right. \\
(\mathrm{g} / \mathrm{g} \text { of NAN })]\} / \mathrm{OB}{ }^{15} \mathrm{~N} \text { APE }(\mathrm{g} / \mathrm{g} \text { of NAN }), \text { and } \\
\text { Microbial NAN flow }(\mathrm{g} / \mathrm{d})=\text { OP NAN flow }(\mathrm{g} / \mathrm{d}) \\
+ \text { OB NAN flow }(\mathrm{g} / \mathrm{d})
\end{gathered}
$$

The NAN content $(\mathrm{g} / \mathrm{g}$ of $\mathrm{DM})$ of the $\mathrm{OB}$ and $\mathrm{OP}$ samples was used to calculate the flow of total microbial biomass. Flow of NANMN was calculated as the difference between total NAN flow and microbial NAN flow. Endogenous $\mathrm{N}$ flows were not determined in this study, as all NANMN was assumed to be dietary in origin. Therefore, RUP flow was estimated by multiplying NANMN by 6.25 , neglecting any contribution of non $-{ }^{15} \mathrm{~N}$ endogenous $\mathrm{N}$ contributions (Lapierre et al., 2008). Rumen degradable protein supply was calculated as total $\mathrm{N}$ intake minus RUP flow. Apparent and true ruminal digestibility of DM, OM, aNDFom, and N were calculated as follows:

$$
\begin{gathered}
\text { Apparent digestibility }=\text { nutrient intake } \\
- \text { omasal nutrient flow, and }
\end{gathered}
$$$$
\text { True digestibility }=\text { nutrient intake }
$$$$
\text { - (omasal nutrient flow - microbial nutrient flow), }
$$

where all intakes and flows are in grams per day. Apparent total-tract digestibility of DM and $\mathrm{OM}$ was determined using the fecal composite with uNDFom as an internal marker. Rumen and total-tract digestibility 
of aNDFom can be considered true digestibility, as the use of sodium sulfite in the aNDFom procedure reduces microbial contamination (Van Soest, 2015).

A comparison of observed values and CNCPS predictions was performed. Cattle characteristics, diet composition, and actual DMI were entered into the CNCPS v. 6.5, and the model was used to predict total omasal $\mathrm{N}$ flow, microbial $\mathrm{N}$ flow, and RUP flow. These values were then compared with the observed values to evaluate the model's ability to predict postruminal nutrient flow. Due to individual animal variation and the limited number of independent observations, observed versus predicted flow comparisons are on a numerical basis only.

\section{Statistical Analyses}

All data were analyzed using SAS version 9.3 (SAS Institute Inc., Cary, NC). Diet chemical composition was analyzed using PROC GLM and means were compared using the LSMEAN statement. All other data were analyzed using the MIXED procedure of SAS version 9.3. Due to a slight negative effect of omasal sampling procedure on intake, milk production and associated intake were determined as the mean of $3 \mathrm{~d}$ before the infusion period began, whereas omasal parameters and associated nutrient intake were determined from data collected during the omasal sampling period. All variables were analyzed according to the following model:

$$
\mathrm{Y}_{\mathrm{ijkl}}=\mu+\mathrm{S}_{\mathrm{i}}+\mathrm{C}_{\mathrm{j}: \mathrm{i}}+\mathrm{P}_{\mathrm{k}}+\mathrm{T}_{\mathrm{l}}+\mathrm{ST}_{\mathrm{il}}+\varepsilon_{\mathrm{ijkl}},
$$

where $\mathrm{Y}_{\mathrm{ijkl}}=$ dependent variable, $\mu=$ overall mean, $\mathrm{S}_{\mathrm{i}}=$ fixed effect of sequence $\mathrm{i}, \mathrm{C}_{\mathrm{j}: \mathrm{i}}=$ random effect of cow within sequence, $\mathrm{P}_{\mathrm{k}}=$ fixed effect of period $\mathrm{k}$, $\mathrm{T}_{1}=$ fixed effect of treatment $1, \mathrm{ST}_{\mathrm{il}}=$ fixed interaction effect of sequence $\mathrm{i}$ and treatment 1 , and $\varepsilon_{\mathrm{ijkl}}=$ residual error. Degrees of freedom were calculated using the Kenward-Roger option. Means were determined using the least squares means statement, and treatment means were compared using the PDIFF option. Statistical significance was considered at $P \leq 0.05$ and trends were considered at $0.05<P \leq 0.10$.

\section{RESULTS AND DISCUSSION}

\section{Diets, Animal Performance, and Rumen Concentration of Metabolites}

Corn silage, alfalfa silage, and Fermenten chemical composition is reported in Table 1. Experimental diets were formulated to be isonitrogenous and isoenergetic. Model predicted RDP was decreased in EXP diets compared with $\mathrm{CON}$ (8.4 vs. $8.0 \%$ of $\mathrm{DM} ; P<0.01$ ) as calculated by the CNCPS v. 6.5 and this was intended in diet formulation. Concentration of aNDFom tended to be greater in EXP diets (30.9 vs. $31.2 \%$ of DM; $P=$ $0.08)$, although this is likely of limited biologic significance given typical variation in feeding management. All other analyzed nutrients were not different between $\operatorname{diets}(P>0.05$; Table 2$)$.

Body weight change over the trial followed typical patterns for peak lactation dairy cattle and was not affected by treatment. Body condition score similarly was not affected (data not shown); all cows averaged $2.25 \pm$ 0.14 (mean $\pm \mathrm{SD}$ ) for the duration of the trial. Rumen degradable $\mathrm{N}$ source had no effect on intake or daily milk, protein, or fat production (Table 3); however, this trial was not specifically designed to assess effects on milk production. Milk urea $\mathrm{N}$ and plasma urea $\mathrm{N}$ concentration increased $(P=0.01)$ in cows fed the EXP diet, and the relationship between rumen $\mathrm{NH}_{3}-\mathrm{N}$ and plasma urea $\mathrm{N}$ is described in Figure 1. The slopes of the lines were not different between treatments $(0.63$ for both CON and EXP; $P=0.67$ ) and were similar to the results observed by Recktenwald et al. (2014). This suggests that Fermenten does not alter the rate of uptake of rumen $\mathrm{NH}_{3}-\mathrm{N}$. Rumen $\mathrm{NH}_{3}-\mathrm{N}$ pool size and concentration was also increased $(P<0.01)$ in EXP cows (Table 4). This, combined with the increase in PUN and MUN in the cattle fed the EXP diet, indicated a possible reduction in utilization of rumen ammonia by microbes and subsequently greater ureagenesis and excretion of $\mathrm{N}$ in milk.

Ammonia- $\mathrm{N}$ concentrations of $\mathrm{CON}$ diets were very close to the minimal optimal concentration of $5 \mathrm{mg}$ $\mathrm{NH}_{3}-\mathrm{N} / \mathrm{dL}$ to support efficient microbial growth as recommended by Satter and Slyter (1974). This is consistent with the desired formulation of rumen available $\mathrm{N}$ to determine the effect of the fermentation byproduct on microbial $\mathrm{N}$ use. The compositing of samples done in the current experiment limit the ability to investigate temporal fluctuations in rumen $\mathrm{NH}_{3}-\mathrm{N}$ concentrations; it is possible that both diets experienced some time below $5 \mathrm{mg} / \mathrm{dL}$. However, it is unlikely that rumen ammonia concentration significantly reduced microbial activity in this study, as no differences were observed in VFA concentration, pool size, or ruminal digestibility of DM, OM, or NDF between treatments (Tables 4 and $5)$.

\section{Rumen and Total-Tract Digestion of DM, $O M$, and NDF}

Intake during the omasal sampling period was not different between diets $(P>0.05$; Table 5$)$. A slight disturbance of the cattle during sampling procedures might have reduced DMI during the omasal sampling 
Table 3. Effect of rumen available nitrogen source on DMI, milk production, and animal performance

\begin{tabular}{lcccc}
\hline & \multicolumn{3}{c}{ Diet $^{2}$} & \\
Item \\
\cline { 2 - 3 } & CON & EXP & SEM & $P$-value \\
\hline DMI, kg/d & 25.5 & 26.4 & 0.9 & 0.34 \\
Milk yield, kg/d & 41.7 & 43.1 & 1.4 & 0.36 \\
ECM, kg/d & 41.7 & 43.1 & 1.9 & 0.48 \\
Milk fat, \% & 3.53 & 3.50 & 0.11 & 0.77 \\
Milk fat, kg/d & 1.47 & 1.51 & 0.08 & 0.60 \\
Milk true protein, \% & 2.85 & 2.86 & 0.07 & 0.86 \\
Milk true protein, kg/d & 1.19 & 1.22 & 0.06 & 0.55 \\
MUN, mg/dL & 10.5 & 13.0 & 0.4 & $<0.01$ \\
Plasma urea N, mg/dL & 8.7 & 11.0 & 0.7 & 0.01 \\
Urine urea N, mg/dL & 30.4 & 48.1 & 19.2 & 0.37 \\
Feed efficiency ${ }^{3}$ & 1.64 & 1.64 & 0.06 & 0.97 \\
BW change, kg/d & 0.29 & 0.39 & 0.12 & 0.58 \\
\hline
\end{tabular}

${ }^{1}$ Values calculated from data collected on d 19 to 21 of each experimental period.

${ }^{2} \mathrm{CON}=3 \%$ of diet DM as urea control mix; EXP $=3 \%$ of diet DM as fermentation byproduct.

${ }^{3} \mathrm{ECM} / \mathrm{DMI}$.

period; therefore, separate intakes are reported for the milk production data versus the omasal sampling data (Tables 3 and 5 , respectively). The average ruminal DM and OM digestibility in the experiment was 59.9 and $67.7 \%$, respectively, and was not different between treatments. Rumen aNDFom digestibility averaged 31.2 and $33.4 \%$ for diets CON and EXP, respectively $(P=0.24)$ when expressed as a percent of total aND-

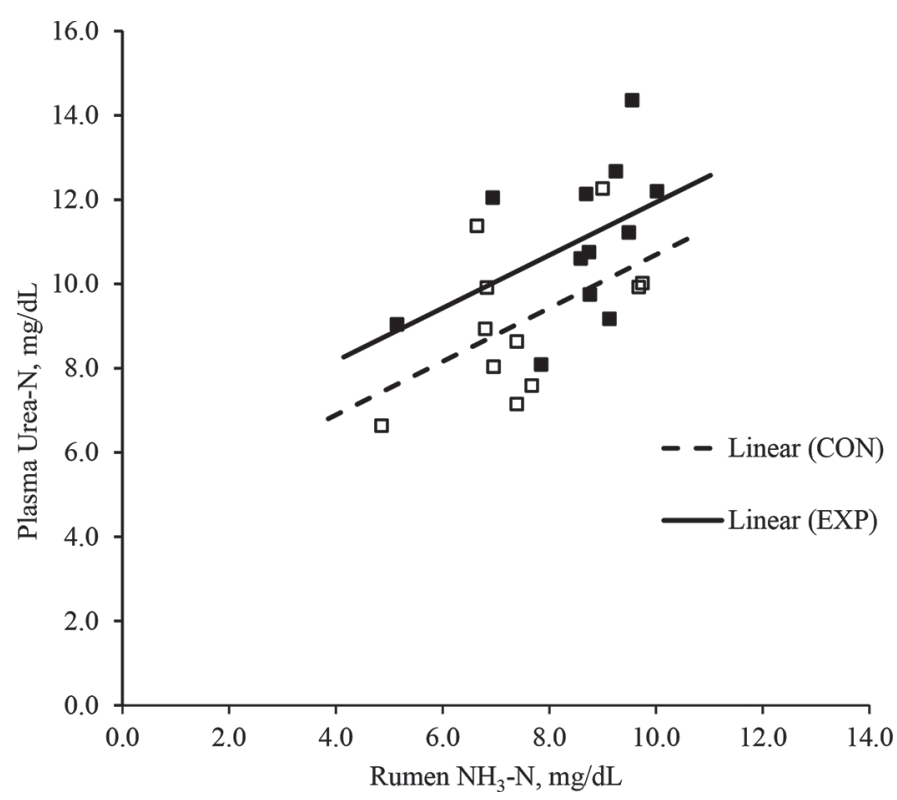

Figure 1. Relationship between rumen $\mathrm{NH}_{3}-\mathrm{N}$ and plasma urea $\mathrm{N}$ in lactating dairy cows fed 2 different sources of rumen available $\mathrm{N}$, where CON $(\square)=3 \%$ of diet DM as urea control mix; $\operatorname{EXP}(\square)=3 \%$ of diet DM as fermentation byproduct meal. The equation representing relationship in cattle fed the CON diet is $\mathrm{y}=0.6338 \mathrm{x}+4.356, \mathrm{R}^{2}$ $=0.27$; the equation describing the relationship in cattle fed the EXP diet is $\mathrm{y}=0.6274 \mathrm{x}+5.663, \mathrm{R}^{2}=0.22$.
Fom. Digestion of the potentially digestible pool was not different among treatments, and averaged 44.9 and $47.4 \%$ for diets CON and EXP, respectively $(P=0.36)$. True OM and DM digestion in the rumen was within the range reported by Huhtanen et al. (2010). Rumen aNDFom digestion was slightly lower than the mean determined by Huhtanen et al. (2010); however, values observed in this study were similar those reported in studies performed with typical North American diets (Brito et al., 2006, 2007). The difference between totaltract and rumen aNDFom digestibility in this experiment indicates that approximately $20 \%$ of the totaltract NDF digestion occurred postruminally. This is at the lower end of the range reported by Huhtanen et al. (2010), yet similar to the summary by Firkins (1997). The discrepancy could be related to the differences in data sets and methodologies represented in each summary. This study used a relatively high level of corn silage as the forage source and would be more similar to the results of Firkins (1997) and the North American diets represented in the Huhtanen et al. (2010) review. North American diets represented the lower end of ruminal NDF digestion presented in the review, likely due to intake and forage type considerations.

The lack of response in aNDFom digestion to ruminal protein source has been observed previously when degradable protein sources were compared (Robinson, 1997; Brito et al., 2007). Brito et al. (2007) reported no difference in apparent ruminal NDF digestion when urea, soybean meal, cottonseed meal, and canola meal were fed, averaging $31 \%$ across diets. It is likely that diets in this study and Brito et al. (2007) provided enough RDP that NDF digestion was not negatively affected. Arroquy et al. (2004) also reported no effect of RDP source on NDF or OM digestion in steers fed 
Table 4. Effect of rumen available nitrogen source on rumen concentration and pool size ${ }^{1}$ of ammonia $\mathrm{N}$ and VFA

\begin{tabular}{lcccc}
\hline & \multicolumn{2}{c}{ Diet $^{2}$} & & \\
\cline { 2 - 3 } Item & CON & EXP & SEM & P-value \\
\hline Ammonia N pool size, g & 4.50 & 5.24 & 0.45 & 0.02 \\
Ammonia N concentration, mg/dL & 5.41 & 6.41 & 0.39 & 0.01 \\
VFA pool size, mol & & & & \\
Total VFA & 8.05 & 8.12 & 0.31 & 0.81 \\
Acetate (A) & 5.23 & 5.30 & 0.16 & 0.71 \\
Propionate (P) & 1.87 & 1.87 & 0.14 & 0.95 \\
Butyrate & 0.73 & 0.73 & 0.03 & 0.97 \\
Isobutyrate & 0.02 & 0.02 & 0.00 & 0.87 \\
Valerate & 0.10 & 0.11 & 0.01 & 0.45 \\
Isovalerate & 0.09 & 0.10 & 0.01 & 0.56 \\
Branched-chain VFA & 0.12 & 0.12 & 0.01 & 0.76 \\
A:P ratio, mol/mol & 2.96 & 2.88 & 0.16 & 0.62 \\
VFA concentration, m $M$ & & & & \\
Total VFA & 97.3 & 99.3 & 3.0 & 0.48 \\
Acetate & 63.6 & 64.8 & 2.2 & 0.55 \\
Propionate & 22.1 & 23.0 & 1.0 & 0.55 \\
Butyrate & 8.9 & 9.0 & 0.4 & 0.69 \\
Isobutyrate & 0.3 & 0.3 & 0.1 & 0.77 \\
Valerate & 1.2 & 1.3 & 0.1 & 0.30 \\
Isovalerate & 1.1 & 1.2 & 0.1 & 0.53 \\
Branched-chain VFA & 1.4 & 1.5 & 0.2 & 0.78 \\
\hline
\end{tabular}

${ }^{1}$ Nutrient concentration $\times$ rumen liquid volume measured from total rumen evacuation.

${ }^{2} \mathrm{CON}=3 \%$ of diet DM as urea control mix; EXP $=3 \%$ of diet DM as fermentation byproduct.

Table 5. Effect of rumen available nitrogen source on digestibility of DM, OM, and NDF

\begin{tabular}{|c|c|c|c|c|}
\hline \multirow[b]{2}{*}{ Item $^{1}$} & \multicolumn{2}{|c|}{ Diet $^{2}$} & \multirow[b]{2}{*}{ SEM } & \multirow[b]{2}{*}{$P$-value } \\
\hline & $\mathrm{CON}$ & EXP & & \\
\hline \multicolumn{5}{|l|}{$\mathrm{DM}$} \\
\hline Intake, $\mathrm{kg} / \mathrm{d}$ & 23.8 & 23.9 & 0.7 & 0.91 \\
\hline Flow at omasal canal, $\mathrm{kg} / \mathrm{d}$ & 16.7 & 16.1 & 0.6 & 0.41 \\
\hline Apparently digested in the rumen, $\mathrm{kg} / \mathrm{d}$ & 7.1 & 7.9 & 0.4 & 0.15 \\
\hline Truly digested in the rumen, ${ }^{3} \mathrm{~kg} / \mathrm{d}$ & 14.3 & 14.2 & 0.4 & 0.90 \\
\hline$\%$ of DMI & 60.3 & 59.6 & 1.4 & 0.72 \\
\hline Total-tract apparent digestibility, \% & 68.6 & 68.2 & 0.5 & 0.47 \\
\hline \multicolumn{5}{|l|}{$\mathrm{OM}$} \\
\hline Intake, $\mathrm{kg} / \mathrm{d}$ & 22.1 & 22.0 & 0.6 & 0.95 \\
\hline Flow at omasal canal, $\mathrm{kg} / \mathrm{d}$ & 13.4 & 12.8 & 0.5 & 0.39 \\
\hline Apparently digested in the rumen, $\mathrm{kg} / \mathrm{d}$ & 8.7 & 9.3 & 0.4 & 0.30 \\
\hline Truly digested in the rumen, ${ }^{3} \mathrm{~kg} / \mathrm{d}$ & 15.0 & 14.9 & 0.4 & 0.77 \\
\hline$\%$ of OM intake & 68.2 & 67.4 & 1.6 & 0.73 \\
\hline Total-tract apparent digestibility, \% & 70.9 & 69.2 & 1.0 & 0.07 \\
\hline \multicolumn{5}{|l|}{ NDF } \\
\hline Intake, $\mathrm{kg} / \mathrm{d}$ & 7.3 & 7.5 & 0.2 & 0.72 \\
\hline Flow at omasal canal, $\mathrm{kg} / \mathrm{d}$ & 5.1 & 5.0 & 0.2 & 0.70 \\
\hline Apparently digested in the rumen, $\mathrm{kg} / \mathrm{d}$ & 2.3 & 2.5 & 0.1 & 0.18 \\
\hline$\%$ of NDF intake & 31.2 & 33.4 & 1.3 & 0.24 \\
\hline$\%$ of pdNDF ${ }^{4}$ intake & 44.9 & 47.4 & 1.9 & 0.36 \\
\hline \multicolumn{5}{|l|}{ Total-tract apparent digestibility, \% } \\
\hline$\%$ of NDF intake & 41.0 & 40.8 & 1.0 & 0.89 \\
\hline$\%$ of pdNDF intake & 59.0 & 57.8 & 1.3 & 0.49 \\
\hline
\end{tabular}

${ }^{1}$ Values calculated from data collected on d 24 to 27 of each experimental period.

${ }^{2} \mathrm{CON}=3 \%$ of diet DM as urea control mix; EXP $=3 \%$ of diet DM as fermentation byproduct.

${ }^{3}$ Corrected for microbial and VFA contribution to flows.

${ }^{4} \mathrm{pdNDF}=$ potentially digestible $\mathrm{NDF}$. 
low quality forage. Apparent total-tract OM digestibility tended to be lower in cows fed EXP diets $(70.9$ vs. $69.2 \%$ for CON and EXP, respectively; $P=0.07$ ). The reason for this is unknown. The relative difference between $\mathrm{OM}$ digestion in the rumen versus total-tract would suggest some changes in postrumen microbial activity or true OM digestion. It is difficult to ascertain the reason for changes in apparent total-tract OM digestion without measures of microbial contribution to fecal OM flow, and therefore true OM digestion. Ultimately, the observed difference is likely of limited biologic importance.

\section{Omasal N Flows and Ruminal N Digestibility}

Nitrogen intake was similar between the 2 diets (Table 6). Compared with CON diets, the inclusion of the fermentation byproduct in EXP diets shifted $18 \mathrm{~g} / \mathrm{d}$ of $\mathrm{N}$ from the ammonia $\mathrm{N}$ pool (PA1) to the soluble AA and peptide pool (PA2) and true protein pool (PB1), according to the CNCPS v. 6.5 protein fractionation scheme (Higgs et al., 2015; Van Amburgh et al., 2015). This shift represents approximately $3 \%$ of total $\mathrm{N}$ intake. The flow of NAN was not different between diets. Nonammonia nonmicrobial $\mathrm{N}$ flow tended to increase in cows fed the EXP diet, whereas microbial NAN flow as a percent of total flow was similar between diets. Brito et al. (2007) reported an opposite effect when soluble true protein replaced urea in diets, and the differences between diets are not immediately clear. A key difference between studies is the diet composition, especially regarding fermentable starch sources and diet NDF content. Diets in the Brito et al. (2007) study averaged $23.9 \%$ NDF content, and the control diet contained considerably more high-moisture ear corn than experimental diets. This might have led to depression of microbial CP synthesis due to possible reduction in rumen $\mathrm{pH}$ and soluble AA $\mathrm{N}$ availability. The lack of increased microbial $\mathrm{N}$ flow in the current study also contrasts with the pretrial expectation of increased microbial flow due to stimulation of microbes with soluble AA and peptides from the byproduct. A meta-analysis of continuous culture studies with fermentation byproducts has previously shown positive effects on microbial $\mathrm{N}$ flow from diets containing the commercial fermentation byproducts Fermenten and BioChlor (Lean et al., 2005). The meta-analysis reported a $0.271 \mathrm{~g} / \mathrm{d}$ (15.7\%) increase in microbial $\mathrm{N}$ flow with fermentation byproduct inclusion using purines as a microbial marker. Assuming a mean purine concentration of 952 $\mathrm{mg} / \mathrm{g}$ of microbial $\mathrm{N}$, as reported by Illg and Stern (1994), the increased microbial $\mathrm{N}$ flow would have been calculated from approximately $258 \mathrm{mg} / \mathrm{d}$ of additional purines flowing from the fermenters fed fermentation byproduct.

Commercial fermentations byproducts are derived from microbial fermentations, and as such could contain relatively high levels of microbial purines. The Fermenten in this study had a $\mathrm{N}$ content of $8.17 \%$ of $\mathrm{DM}(51.1 \% \mathrm{CP} / 6.25)$. Assuming $75 \%$ of the $\mathrm{N}$ in the fermentation byproduct was of microbial origin (Broderick et al., 2000), this would correspond to $0.0613 \mathrm{~g}$ of microbially derived $\mathrm{N} / \mathrm{g}$ of product. Commercial fermentations are typical performed using Escherichia coli or Corynebacterium glutamicum, and purine content can be estimated to be $10 \%$ of cell DM under commercial growth conditions (Neidhart, 1996). Assuming a cellular $\mathrm{N}$ content of $8.5 \%$ of $\mathrm{DM}$, this would correspond to $1,176 \mathrm{mg}$ of purines/g of microbial $\mathrm{N}(10 / 8.5)$. Therefore, it is possible that fermentation byproducts could contain approximately $72.1 \mathrm{mg}$ of purines/g of product $(0.0613 \mathrm{~g}$ of microbial $\mathrm{N} / \mathrm{g}$ of product $\times 1,176$ $\mathrm{mg} / \mathrm{g}$ of microbial N). Lean et al. (2005) used an average inclusion rate of $3.6 \mathrm{~g} / \mathrm{d}$ of fermentation byproduct, which might corresponds to an input of $260 \mathrm{mg} / \mathrm{d}$ more dietary purines relative to control diets, which is very similar to the estimated increase in purine outflow of $258 \mathrm{mg} / \mathrm{d}$ associated with the $0.271 \mathrm{~g} / \mathrm{d}$ increase in apparent microbial $\mathrm{N}$ flow reported by Lean et al. (2005). This clearly presents the opportunity for bias toward overestimation of microbial protein flow when using purines as a microbial marker. It is uncertain if this possible bias would be present using purines or purine derivatives during in vivo experiments with fermentation byproducts. Broderick et al. (2000) tested several fermentation byproducts in vivo versus urea control and reported no significant change in microbial $\mathrm{CP}$ flows as estimated using purine derivatives. Use of purine derivatives might have limited the ability to pick up significant differences in that study relative to the current study, as these methods have lower precision and accuracy compared with techniques using ${ }^{15} \mathrm{~N}$, and tend to underestimate microbial $\mathrm{N}$ flow in high producing cows (Reynal et al., 2005).

In the present study, the 65-g difference in NANMN outflow was more than 3 times the 18-g difference in true soluble protein inflow associated with diet composition and intake. This indicates that the inclusion of the fermentation byproduct in EXP diets had an associative effect on protein degradation of other feedstuffs in the rumen; in effect, sparing RDP allowed more feed true protein to escape the rumen. Thus, when using NANMN to calculate diet RUP concentration, diets contained 5.0 and $6.7 \%$ of diet DM as RUP in CON and EXP diets, respectively $(P=0.04)$. True ruminal $\mathrm{N}$ digestibility was $15 \%$ lower in EXP diets $(68.7$ 
Table 6. Effect of rumen available nitrogen source on omasal nitrogen flow and digestibility

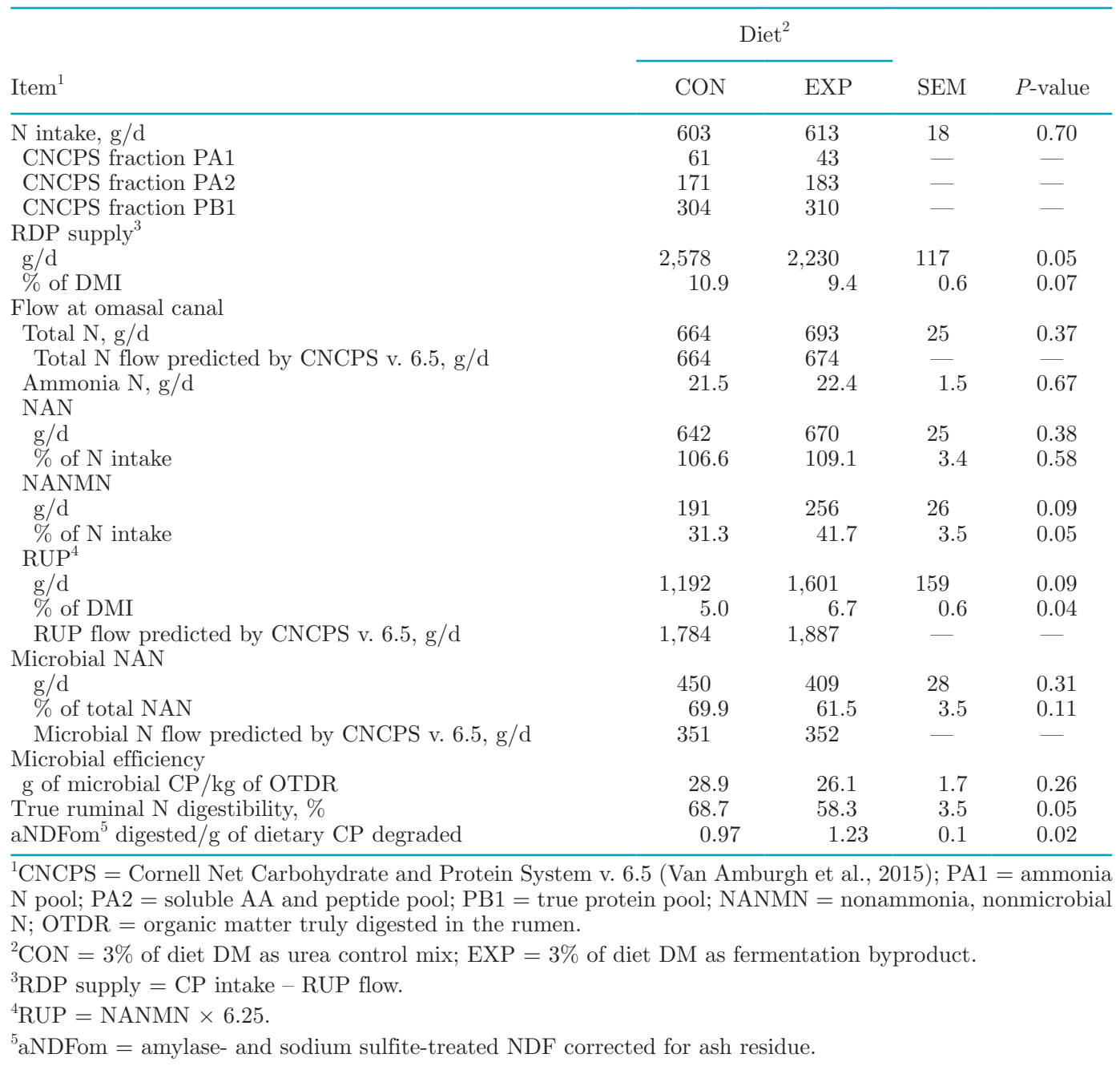

vs. $58.3 \%$ for $\mathrm{CON}$ and EXP, respectively; $P=0.05)$. No differences were observed in efficiency of microbial $\mathrm{CP}$ synthesis per gram of OM digested in the rumen. Uptake of AA N by cellulolytic bacteria has previously been assumed to be minimal to nonexistent, resulting in the assumption that $\mathrm{NH}_{3}-\mathrm{N}$ is the sole source of $\mathrm{N}$ for microbial protein synthesis in the rumen (Russell et al., 1992). However, more recent studies have clearly demonstrated stimulatory effects of AA $\mathrm{N}$ on cellulolytic populations (Atasoglu et al., 2001; Yang, 2002), which could possibly explain the results reported here.

Rumen protein degradation was decreased in cows fed the EXP diet; however, rumen $\mathrm{NH}_{3}-\mathrm{N}$ pool size, concentration, and plasma urea $\mathrm{N}$ increased relative to cows fed the CON diet. Although this seems like a counterintuitive result, one must consider that protein degradation does not always proceed completely to ammonia production, thus elevating rumen ammonia concentration. Production of $\mathrm{NH}_{3}-\mathrm{N}$ is a result of complex microbial and enzymatic activities by a community of mixed rumen microbes. Final rumen $\mathrm{NH}_{3-}$ $\mathrm{N}$ concentration is a dynamic balance of degradation processes, uptake by rumen microbes, passage rates, $\mathrm{NH}_{3}-\mathrm{N}$ absorption, and $\mathrm{N}$ recycling. In this study, it is possible the fermentation byproduct preferentially suppressed specific populations of proteolytic bacteria, allowing other groups with high affinity for soluble AA and peptides to benefit, such as hyper ammoniaproducing bacteria (Russell et al., 1988). This group of microbes can account for disproportional amounts of ammonia production relative to their abundance in the rumen microbial population (Rychlik and Russell, 2000). Differential effects of fermentation byproduct on specific microbial populations could explain the results reported here, and may warrant further investigation.

Another possible mechanism for decreased CP degradation and increased rumen $\mathrm{NH}_{3}-\mathrm{N}$ could be related to the different rates of degradation of proteins versus 
peptides in the rumen. Initial protein hydrolysis is rapid and occurs extracellularly, and previous in vitro work has demonstrated that subsequent peptide degradation and uptake is a rate-limiting step for microbial protein synthesis (Broderick and Craig, 1989; Wallace et al., 1990). In the rumen, initial disruption of the tertiary structure of feed protein could allow peptides and AA to solubilize and flow with the liquid pool, thus escaping further degradation in the rumen. In the current experiment, it is possible that peptide hydrolysis or uptake by rumen microbes (or both) was decreased, resulting in increased undegraded feed $\mathrm{N}$ flow in the soluble phase. Although the mechanism is unknown, inhibitors to peptide hydrolysis or uptake could be present in the fermentation byproduct. Commercial AA fermentations often use strains of bacteria specifically selected for increased AA production and excretion of peptides and AA. These specialized microorganisms also often have natural or artificial alterations in cellular feedback mechanisms, membrane permeability, cellular transport mechanisms, and substrate preferences (Ikeda, 2003). In a commercial fermentation, peptide degradation and AA uptake would be considered a negative trait. If signaling factors related to these traits are still present in the byproduct, it could provide a mechanism to influence rumen microbial proteolytic activity. Of interest would be any possible inhibitors to protease or peptidase activity and changes in cell permeability. Further research into this area might provide a more specific mode of action for the results observed in this study.

Although urea $\mathrm{N}$ recycling was not determined in this study, it is also possible that urea entry from the plasma pool allowed for elevated rumen $\mathrm{NH}_{3}-\mathrm{N}$ levels (Marini and Van Amburgh, 2003; Valkeners et al., 2007). This might occur if postruminal protein metabolism, rather than rumen digestion, caused the increased ureagenesis relative to excretion. This would elevate the concentration of urea in the plasma pool and leading to increased net influx into the rumen relative to the cows fed the CON diet. Without recycling information, the direction of $\mathrm{N}$ movement between these pools is unclear.

Ultimately, the sparing effect on degradable peptides and AA presents a key opportunity to use fermentation byproduct meal in conjunction with less expensive homegrown forages and protein feedstuffs such as alfalfa silage and untreated soybean meal. In such diets, overfeeding of degradable protein is common, as supply of metabolizable protein can be insufficient even at high levels of dietary CP. Future studies might investigate the ability of targeted feeding of degradable protein sources with fermentation byproducts to increase the income over feed cost and $\mathrm{N}$ utilization in $\mathrm{N}$ efficient feeding schemes. This might be preferable to providing the cow with higher levels of RUP, as is common when utilizing feedstuffs such as blood meal or enzymatically treated soybean meal. Many of the strategies used to decrease rumen degradability can lead to decreased total-tract digestion, thus negating some of the benefit of the increased RUP, and increased $\mathrm{N}$ excreted into manure.

\section{CNCPS-Predicted Versus Observed N Flows}

Total omasal $\mathrm{N}$ flow was well predicted by the model, whereas microbial $\mathrm{N}$ flow appeared to be underpredicted (Table 6). Alternatively, recent evaluations of CNCPS v. 6.5 (Van Amburgh et al., 2015) against omasal study data showed good agreement between predicted and observed microbial $\mathrm{N}$ flows. The difference between predicted and observed microbial flows is 16 to $28 \%$ below the measured flow, and this amount of $\mathrm{N}$ would be similar to the protozoal contribution of the microbial flow, a microbial pool not described in this version of the CNCPS. Broderick et al. (2010) reported similar underprediction of microbial $\mathrm{N}$ flow when comparing observed microbial CP flow versus NRC (2001) predictions, especially at higher levels of microbial flow. This is not surprising, considering the rumen sub-model of the CNCPS and NRC are built from similar data sets. Combined, the 2 systems are used to balance diets for much of the US dairy industry. Thus, differences in microbial AA versus feed AA profiles might lead to a tendency for nutritionists to rely more on supplemental AA sources to meet the AA requirements of the cows. Correction of these biases might reduce dependence on RUP sources to supply metabolizable AA, which could have beneficial effects on farm economics and sustainability.

Rumen undegraded protein flow was overpredicted by 50 and $18 \%$ in CON and EXP diets, respectively. The gram amount of predicted RUP were fairly similar between diets, indicating that the model is not accounting for the protein sparing effect of fermentation byproducts. Within the structure of the model, microbial populations are stimulated when peptide balance is positive (Russell et al., 1992); however, the assigned rates of degradation of many feedstuffs result in high peptide balance in most simulations. Updates to the feed library (Higgs et al., 2015) and model (Van Amburgh et al., 2010, 2015) have sought to correct this; however, the current structure of the rumen sub-model in CNCPS v. 6.5 has limited the ability to describe microbial $\mathrm{N}$ dynamics in a more mechanistic way, especially the interactions and associative affects between microbial populations and substrate. Endogenous N contributions to RUP flow are not differentiated in this study and are not mechanistically described in 
the CNCPS. This would lead to additional differences between model predictions and observations in this experiment.

\section{CONCLUSIONS}

In this study, the inclusion of a fermentation byproduct versus urea and wheat middlings resulted in changes in omasal $\mathrm{N}$ flows. Previous in vitro studies utilizing the same product have observed increases in apparent microbial $\mathrm{N}$ flows, which was attributed to stimulation of rumen microbial growth by soluble AA and peptides. In this study, it is unlikely that differences in flow were due to the stimulation of rumen microbes. Total NAN and microbial $\mathrm{N}$ flow was not different between diets; however, we did observe a tendency for increased in NANMN flow at the omasal canal. Rumen undegraded protein (\% of DMI) was significantly increased in cows fed the fermentation byproduct. The $65-\mathrm{g}$ difference in NANMN flow was unlikely to be caused by the hypothesized stimulation of microbes by soluble AA and peptides because the treatments only provided an additional $18 \mathrm{~g}$ of soluble AA N. It is more likely that a different factor present in the fermentation byproduct altered microbial degradation or microbial uptake of $\mathrm{N}$ (or both) through an unknown mechanism, resulting in a $15 \%$ decrease in apparent ruminal protein degradation. This result may be beneficial in feeding applications where excess RDP is fed, as is typical in many feeding applications using fermented forages and byproducts from human food and fiber production.

\section{ACKNOWLEDGMENTS}

The authors thank Arm \& Hammer Animal Nutrition for funding support; A. Zontini, A. LaPierre, and M. Horton (Cornell University, Ithaca, NY) for assisting with sample collection, processing, and analysis; and the research staff and farm crew at the Cornell University Ruminant Center, especially W. Prokop, L. Furman, and Z. Leno. Portions of this manuscript appear in S. Fessenden's PhD dissertation (Fessenden, 2016) and conference proceedings (Fessenden and Van Amburgh, 2016).

\section{REFERENCES}

Ahvenjärvi, S., A. Vanhatalo, P. Huhtanen, and T. Varvikko. 2000. Determination of reticulo-rumen and whole-stomach digestion in lactating cows by omasal canal or duodenal sampling. Br. J. Nutr. 83:67-77. https://doi.org/10.1017/S0007114500000106.

AOAC International. 2005. Official Methods of Analysis. 18th ed. AOAC International, Gaithersburg, MD.

Arroquy, J. I., R. C. Cochran, T. A. Wickersham, D. A. Llewellyn, E. C. Titgemeyer, T. G. Nagaraja, and D. E. Johnson. 2004. Effects of type of supplemental carbohydrate and source of supplemental rumen degradable protein on low quality forage utilization by beef steers. Anim. Feed Sci. Technol. 115:247-263. https://doi.org/10 .1016/j.anifeedsci.2004.01.007.

Atasoglu, C., C. J. Newbold, and R. J. Wallace. 2001. Incorporation of $[15 \mathrm{~N}]$ ammonia by the cellulolytic ruminal bacteria Fibrobacter succinogenes BL2, Ruminococcus albus SY3, and Ruminococcus flavefaciens 17. Appl. Environ. Microbiol. 67:2819-2822. https://doi .org/10.1128/AEM.67.6.2819-2822.2001.

Brito, A. F., G. A. Broderick, and S. M. Reynal. 2006. Effect of varying dietary ratios of alfalfa silage to corn silage on omasal flow and microbial protein synthesis in dairy cows. J. Dairy Sci. 89:39393953. https://doi.org/10.3168/jds.S0022-0302(06)72436-5.

Brito, A. F., G. A. Broderick, and S. M. Reynal. 2007. Effects of different protein supplements on omasal nutrient flow and microbial protein synthesis in lactating dairy cows. J. Dairy Sci. 90:1828 1841. https://doi.org/10.3168/jds.2006-559.

Broderick, G., and W. M. Craig. 1989. Metabolism of peptides and amino acids during in vitro protein degradation by mixed rumen organisms. J. Dairy Sci. 72:2540-2548. https://doi.org/10.3168/ jds.S0022-0302(89)79394-2.

Broderick, G. A., N. De Leon, and Y. Nakamura. 2000. Potential of fermentation byproducts as nitrogen supplements for lactating dairy cows. J. Dairy Sci. 83:2548-2556. https://doi.org/10.3168/ jds.S0022-0302(00)75147-2.

Broderick, G. A., P. Huhtanen, S. Ahvenjärvi, S. M. Reynal, and K. J. Shingfield. 2010. Quantifying ruminal nitrogen metabolism using the omasal sampling technique in cattle - A meta-analysis. J. Dairy Sci. 93:3216-3230. https://doi.org/10.3168/jds.2009-2989.

Broderick, G. A., and N. R. Merchen. 1992. Markers for quantifying microbial protein synthesis in the rumen. J. Dairy Sci. 75:26182632. https://doi.org/10.3168/jds.S0022-0302(92)78024-2.

Chaney, A. L., and E. P. Marbach. 1962. Modified reagents for determination of urea and ammonia. Clin. Chem. 8:130-132.

Cotta, M. A., and J. B. Russell. 1982. Effect of peptides and amino acids on efficiency of rumen bacterial protein synthesis in continuous culture. J. Dairy Sci. 65:226-234. https://doi.org/10.3168/jds .S0022-0302(82)82181-4.

Fessenden, S. W. 2016. Amino acid supply in dairy cattle. PhD Diss. Department of Animal Science, Cornell University, Ithaca, NY. https://ecommons.cornell.edu/handle/1813/45365.

Fessenden, S. W., T. J. Hackmann, D. A. Ross, E. Block, A. Foskolos, and M. E. Van Amburgh. 2019. Rumen digestion kinetics, microbial yield, and omasal flows of nonmicrobial, bacterial, and protozoal amino acids in lactating dairy cattle fed fermentation by-products or urea as a soluble nitrogen source. J. Dairy Sci. 102:3036-3052. https://doi.org/10.3168/jds.2018-15448.

Fessenden, S. W., and M. E. Van Amburgh. 2016. Characterization of non-nutritive factors of feeds for model development. Pages 155-169 in Proc. Cornell Nutrition Conference, Syracuse, NY. Cornell University, Ithaca, NY. Accessed Mar. 15, 2017. https:// ecommons.cornell.edu/handle/1813/44741.

Firkins, J. L. 1997. Effects of feeding nonforage fiber sources on site of fiber digestion. J. Dairy Sci. 80:1426-1437. https://doi.org/10 .3168/jds.S0022-0302(97)76072-7.

France, J., and R. Siddons. 1986. Determination of digesta flow by continuous market infusion. J. Theor. Biol. 121:105-119. https:// doi.org/10.1016/S0022-5193(86)80031-5.

Higgs, R. J., L. Chase, D. Ross, and M. Van Amburgh. 2015. Updating the Cornell Net Carbohydrate and Protein System feed library and analyzing model sensitivity to feed inputs. J. Dairy Sci. 98:63406360. https://doi.org/10.3168/jds.2015-9379.

Huhtanen, P., S. Ahvenjärvi, G. A. Broderick, S. M. Reynal, and K. J. Shingfield. 2010. Quantifying ruminal digestion of organic matter and neutral detergent fiber using the omasal sampling technique in cattle - A meta-analysis. J. Dairy Sci. 93:3203-3215. https://doi .org/10.3168/jds.2009-2988.

Huhtanen, P., P. G. Brotz, and L. D. Satter. 1997. Omasal sampling technique for assessing fermentative digestion in the forestomach of dairy cows. J. Anim. Sci. 75:1380-1392. https://doi.org/10 $.2527 / 1997.7551380 \mathrm{x}$. 
Huhtanen, P., and A. N. Hristov. 2009. A meta-analysis of the effects of dietary protein concentration and degradability on milk protein yield and milk N efficiency in dairy cows. J. Dairy Sci. 92:32223232. https://doi.org/10.3168/jds.2008-1352.

Ikeda, M. 2003. Amino acid production processes. Pages 1-35 in Microbial Production of L-Amino Acids. Springer, Berlin, Germany.

Illg, D. J., and M. D. Stern. 1994. In vitro and in vivo comparisons of diaminopimelic acid and purines for estimating protein synthesis in the rumen. Anim. Feed Sci. Technol. 48:49-55. https://doi.org/ 10.1016/0377-8401(94)90111-2.

Lapierre, H., D. R. Ouellet, R. Berthiaume, R. Martineau, G. Holtrop, and G. E. Lobley. 2008. Distribution of $15 \mathrm{~N}$ in amino acids during 15N-leucine infusion: Impact on the estimation of endogenous flows in dairy cows. J. Dairy Sci. 91:2702-2714. https://doi.org/10 .3168/jds.2007-0871.

Lean, I. J., T. K. Webster, W. Hoover, W. Chalupa, C. J. Sniffen, E. Evans, E. Block, and A. R. Rabiee. 2005. Effects of BioChlor and Fermenten on microbial protein synthesis in continuous culture fermenters. J. Dairy Sci. 88:2524-2536. https://doi.org/10.3168/ jds.S0022-0302(05)72930-1.

Marini, J. C., and M. E. Van Amburgh. 2003. Nitrogen metabolism and recycling in Holstein heifers. J. Anim. Sci. 81:545-552. https:/ /doi.org/10.2527/2003.812545x.

Mertens, D. R. 2002. Gravimetric determination of amylase-treated neutral detergent fiber in feeds with refluxing in beakers or crucibles: Collaborative study. J. AOAC Int. 85:1217-1240.

Neidhart, F. 1996. Escherichia coli and Salmonella: Cellular and Molecular Biology, vol. II. F. C Neidhardt, J. L. Ingraham, K. B. Low, B. Magasanik, M. Schaechter, and H. E. Umbarger, ed. American Society for Microbiology, Washington, DC.

NRC. 2001. Nutrient Requirements of Dairy Cattle. 7th rev. ed. Natl. Acad. Press, Washington, DC.

Penner, G. B., L. Guan, and M. Oba. 2009. Effects of feeding Fermenten on ruminal fermentation in lactating Holstein cows fed two dietary sugar concentrations. J. Dairy Sci. 92:1725-1733. https:// doi.org/10.3168/jds.2008-1706.

Raffrenato, E., D. A. Ross, and M. E. Van Amburgh. 2018. Development of an in vitro method to determine rumen undigested aNDFom for use in feed evaluation. J. Dairy Sci. 101:9888-9900. https: //doi.org/10.3168/jds.2018-15101.

Recktenwald, E. B., D. A. Ross, S. W. Fessenden, C. J. Wall, and M. E. Van Amburgh. 2014. Urea N recycling in lactating dairy cows fed diets with 2 different levels of dietary crude protein and starch with or without monensin. J. Dairy Sci. 97:1611-1622. https://doi .org $/ 10.3168 /$ jds.2013-7162.

Reynal, S. M., and G. A. Broderick. 2005. Effect of dietary level of rumen-degraded protein on production and nitrogen metabolism in lactating dairy cows. J. Dairy Sci. 88:4045-4064. https://doi .org/10.3168/jds.S0022-0302(05)73090-3.

Reynal, S. M., G. A. Broderick, and C. Bearzi. 2005. Comparison offour markers for quantifying microbial protein flow from the rumen of lactating dairy cows. J. Dairy Sci. 88:4065-4082. https:// doi.org/10.3168/jds.S0022-0302(05)73091-5.

Robinson, P. H. 1997. Modifying duodenal flow of amino acids by manipulation of dietary protein sources. Can. J. Anim. Sci. 77:241251. https://doi.org/10.4141/A96-031.

Russell, J. B., J. D. O'Connor, D. G. Fox, P. J. Van Soest, and C. J. Sniffen. 1992. A net carbohydrate and protein system for evaluating cattle diets: I. Ruminal fermentation. J. Anim. Sci. 70:35513561. https://doi.org/10.2527/1992.70113551x.
Russell, J. B., H. J. Strobel, and G. J. Chen. 1988. Enrichment and isolation of a ruminal bacterium with a very high specific activity of ammonia production. Appl. Environ. Microbiol. 54:872-877.

Rychlik, J. L., and J. B. Russell. 2000. Mathematical estimations of hyper-ammonia producing ruminal bacteria and evidence for bacterial antagonism that decreases ruminal ammonia production. FEMS Microbiol. Ecol. 32:121-128. https://doi.org/10.1111/j .1574-6941.2000.tb00706.x.

Satter, L. D., and L. L. Slyter. 1974. Effect of ammonia concentration on rumen microbial protein production in vitro. Br. J. Nutr. 32:199-208. https://doi.org/10.1079/BJN19740073.

Siddons, R. C., J. Paradine, D. E. Beever, and P. R. Cornell. 1985. Ytterbium acetate as a particulate-phase digesta-flow marker. Br. J. Nutr. 54:509-519. https://doi.org/10.1079/BJN19850136.

Siegfried, V., H. Ruckemann, and G. Stumpf. 1984. Eine HPLC-methode zur bestimmung organischer säuren in silagen. Landwirtsch. Forsch. 37:298-304.

Tylutki, T. P., D. G. Fox, V. M. Durbal, L. O. Tedeschi, J. B. Russell, M. E. Van Amburgh, T. R. Overton, L. E. Chase, and A. N. Pell. 2008. Cornell Net Carbohydrate and Protein System: A model for precision feeding of dairy cattle. Anim. Feed Sci. Technol. 143:174202. https://doi.org/10.1016/j.anifeedsci.2007.05.010.

Udén, P., P. E. Colucci, and P. J. Van Soest. 1980. Investigation of chromium, cerium and cobalt as markers in digesta. Rate of passage studies. J. Sci. Food Agric. 31:625-632. https://doi.org/10 $.1002 /$ jsfa.2740310702.

Valkeners, D., H. Lapierre, J. C. Marini, and D. R. Ouellet. 2007. Effects of metabolizable protein supply on nitrogen metabolism and recycling in lactating dairy cows. Pages $417-418$ in Energy and Protein Metabolism and Nutrition. I. Ortigues-Marty, ed. EAAP Publication. Wageningen Acad. Publ., Wageningen, the Netherlands.

Van Amburgh, M. E., L. E. Chase, T. R. Overton, D. A. Ross, E. B. Recktenwald, R. J. Higgs, and T. P. Tylutki. 2010. Updates to the Cornell Net Carbohydrate and Protein System v6.1 and implications for ration formulation. Pages 144-159 in Proc. Cornell Nutrition Conference, Syracuse, NY. Cornell University, Ithaca, NY.

Van Amburgh, M. E., E. Collao-Saenz, R. Higgs, D. Ross, E. Recktenwald, E. Raffrenato, L. Chase, T. Overton, J. Mills, and A. Foskolos. 2015. The Cornell Net Carbohydrate and Protein System: Updates to the model and evaluation of version 6.5. J. Dairy Sci. 98:6361-6380. https://doi.org/10.3168/jds.2015-9378.

Van Soest, P. J. 2015. The Detergent System for Analysis of Foods and Feeds. Cornell University, Ithaca, NY.

Wallace, R. J., N. McKain, and C. J. Newbold. 1990. Metabolism of small peptides in rumen fluid. Accumulation of intermediates during hydrolysis of alanine oligomers, and comparison of peptidolytic activities of bacteria and protozoa. J. Sci. Food Agric. 50:191-199. https://doi.org/10.1002/jsfa.2740500207.

Whitehouse, N. L., V. Olson, C. Schwab, W. Chesbrot, K. Cunningham, and T. Lykos. 1994. Improved techniques for dissociating particle-associated mixed ruminal microorganisms from ruminal digesta solids. J. Anim. Sci. 72:1335-1343. https://doi.org/10 $.2527 / 1994.7251335 x$.

Yang, C. M. J. 2002. Response of forage fiber degradation by ruminal microorganisms to branched-chain volatile fatty acids, amino acids, and dipeptides. J. Dairy Sci. 85:1183-1190. https://doi.org/10 $.3168 /$ jds.S0022-0302(02)74181-7. 